\title{
PANDANGAN HUKUM PIDANA ISLAM \\ MENGENAI KEKERASAN FISIK TERHADAP ANAK
}

\author{
Taufik Hidayat \\ Fakultas Syariah IAIN Imam Bonjol Padang \\ Jl. M. Yunus Lubuk Lintah \\ e-mail: taufiiq_hidaayah@yahoo.com
}

\begin{abstract}
In order to provide solutions concerning with physical abuses toward children, Indonesia has issued special regulation, namely UU No. 35 tabun 2014 about Perubaban (amendment) UU No. 23 Tabun 2002 about Child Protection. In line with this regulation, a study was carried out to figure out perspectives of Islamic civil law toward children's physical abuses. This study belonged to normative yuridis through library study and employing yuridis normative analysis technique. The study showed that probibitions against children's physical abuses were supported by the second Islamic civil law, namely hifžhan-nafs. However, using physical punishments are tolerated for reasons which have pointed out by the law. In addition, death penalty, imprison, and fine payment are similar to Islamic civil law with minor differences in implementation.
\end{abstract}

Kata kunci: hukum pidana Islam, kekerasan fisik, anak

\section{PENDAHULUAN}

Salah satu nikmat Allah yang diberikan Anak adalah karunia Allah Swt sebagai hasil perkawinan ayah dan ibu. Dalam kondisi normal ia adalah belahan jantung tempat bergantung di hari tua penerus cita-cita bangsa. Diakui bahwa dalam masa pertumbuhan baik secara fisik maupun mental anak membutuhkan perawatan, pembinaan agama, pendidikan, perlindungan khusus, serta perlindungan hukum baik sebelum maupun sesudah lahir. Di samping itu, diakui dan disadari bahwa keluarga dan masyarakat merupakan lingkungan alami bagi tumbuh kembang anak. Dalam perkembangan kepribadian anak secara utuh dan serasi akan membutuhkan lingkungan yang penuh kasih sayang dan diharapkan anak menghormati dan menjunjung tinggi norma agama, norma hukum serta normanorma lainnya agar mereka kelak mampu memikul tanggungjawab.
Ada salah satu masalah dalam kriminalitas yang terus terjadi yaitu kekerasan terhadap anak. Kekerasan terhadap anak dalam hukum positif negara Indonesia merupakan suatu tindak pidana. Barker (1987: 23) mendefenisikan child abuse : "the recurrent infliction of physical or emotional injury on a deependet minor, trogh intentional beatings, uncontroled corporal punishment, persitent redicule and degradation, or sexual abose, usually comit.th.ed by parents or other in carge of the child's care" (kekerasan terhadap anak adalah tindakan melukai berulang-ulang baik secara fisik dan emosional terhadap anak yang ketergantungan, melalui desakan hasrat, hukuman badan yang tidak terkendali, degradasi dan cemoohan permanen atau kekerasan seksual, biasanya dilakukan pada orang tua atau pihak lain yang seharusnya merawat anak).

Tindak kekerasan terhadap anak seringkali tidak mudah diungkap, karena kekerasan terhadap anak, khususnya di dalam keluarga, 
pada hakekatnya bersifat pribadi. Hal ini didukung pula oleh persepsi masyarakat bahwa persoalan-persoalan yang terjadi dalam keluarga adalah persoalan interen keluarga dan tidak layak untuk dicampuri. Persepsi ini menimbulkan sikap diam atau pasif dari masyarakat sekitar anak, sehingga budaya kekerasan fisik terhadap anak tetap berlangsung dan kelangsungan hidup anak menjadi lebih terancam.

Kekerasan terhadap anak seringkali diidentikan dengan kekerasan kasat mata, seperti kekerasan fisikal dan seksual. Padahal, kekerasan yang bersifat psikis dan sosial (struktural) juga membawa dampak buruk dan permanen terhadap anak. Karenannya, istilah child abouse atau perlakuan salah terhadap anak bisa terentang mulai dari yang bersifat fisik (phsycal abuse) hingga seksual (sexsual abuse); dari yang bermakna psikis (mental abuse) hingga sosial (social abuse) yang berdimensi kekerasan struktural (Abu Huraerah, 2006: 22).

Untuk menanggulanginya telah terjadi dua kali perubahan UU No. 23 tahun 2002 tentang Perlindungan Anak. Perubahan pertama yaitu UU No. 35 tahun 2014 tentang Perubahan UU No. 23 Tahun 2002 tentang Perlindungan Anak dan perubahan kedua dikeluarkannya PERPPU No. 1 Tahun 2016 tentang perubahan kedua UU No. 23 tahun 2002 tentang perlindungan anak. Kasus kekerasan terhadap anak sulit diungkap kepermukaan atau merupakan fenomena gunung es meskipun kasusnya sering teridentifikasi.

Perlu dikemukakan di sini bahwa perhatian syariat Islam terhadap perlindungan anak sudah dimulai sejak kurang lebih 1398 tahun yang lalu. Islam selalu memelihara kepentingan anak bukan hanya setelah lahir, melainkan semenjak ia masih berada dalam kandungan. Islam secara khusus telah menggariskan hak-hak yang harus diberikan pada anak.

Dalam Alquran surat al-Balad ayat 1, 2, dan

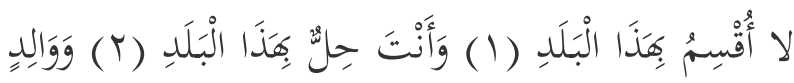

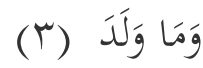

Aku benar-benar bersumpah dengan kota ini (Mekah). Dan kamu (Muhammad) bertempat di kota Mekah ini. Dan demi bapak dan anaknya. (Q.S. al-Balad [90]: 1-3).

Dalam ayat di atas Allah Swt telah bersumpah dengan anak sebagai bukti kecintaan Tuhan terhadap anak. Pelajaran yang diberitahu oleh Allah Swt melalui sumpah-Nya, bahwa Allah Swt memenuhi janji-Nya untuk penaklukan kota Mekkah dari tangan kafir Quraiys, menyelamatkan manusia dan juga anakanak.

\section{METODE PENELITIAN}

Penelitian ini adalah penelitian hukum normatif melalui penelitian perpustakaan. Adapun sumber data yang dipergunakan adalah sumber data sekunder yang mencakup:

1. Bahan hukum primer yaitu UU No. 35 Tahun 2014 tentang perubahan UU No. 23 tahun 2002 tentang Perlindungan Anak, Alquran dan Hadis.

2. Bahan hukum sekunder yaitu penjelasan undang-undang, hasil penelitian hukum, kitab-kitab tafsir, ushûl figh dan figh.

3. Bahan hukum tersier yakni kamus hukum dan ensikplopedi hukum.

Dalam pengolahan data yang penulis peroleh, penulis akan menggunakan teknik analisis yuridis normatif sesuai dengan metode penelitian yang penulis gunakan yaitu penelitian hukum normatif, yang meliputi tahap-tahap sebagai berikut:

1. Identifikasi bahan hukum tertulis yaitu identifikasi kekerasan fisik yang terdapat dalam UU No. 35 Tahun 2014;

2. Merumuskan pengertian-pengertian hukum yaitu penulis akan merumuskan pengertian 
kekerasan fisik dalam konsep hukum pidana Islam.

3. Pembentukan standar-standar hukum dengan memperhatikan pengertian tindak pidana dan unsur-unsur tindak pidana dalam hukum pidana Islam.

4. Perumusan kaidah-kaidah hukum.

Dalam menetukan hukum kekerasan fisik terhadap anak menurut pandangan hukum Islam, pertama penulis akan berpedoman kepada sumber hukum Islam yang tertulis (nushûs) yaitu Alquran dan Hadis yang juga merupakan dalil hukum Islam yang disepakati ('adillah mutthfaq 'alaihâ). Penggalian hukum Islam dari Alquran dan hadis ini juga sesuai dengan asas legalitas dalam fiqh jinâyah yaitu:

$$
\text { لا جريمة ولا عقوبة بلا نص }
$$

Tidak ada tindak pidana dan tidak ada hukuman tanpa adanya aturan

Setelah itu penulis akan berpedoman kepada ijmấ' dan qiyâs karena juga merupakan dalil hukum Islam yang disepakati ('adillah mutthafaq 'alaihâ).

\section{PEMBAHASAN}

Anak mempunyai arti yang sangat penting dalam kehidupan manusia. Ia merupakan mata rantai dan proses pelanjut keberadaan manusia dari generasi ke generasi. Ia adalah manusia masa depan. Dalam konteks yang lebih khusus (konteks keluarga) anak merupakan penerus keturunan. Selain itu, telah menjadi naluri manusia bahwa mereka mendambakan anakanak mereka sebagai penyambung keturunan yang baik dan menyenangkan hati.

Kehadiran anak dinanti-nantikan oleh setiap keluarga baru, sebagai penerus keturunan mereka. Tangisan bayi yang baru lahir akan disambut dengan penuh gembira dan harapan oleh kedua orang tuanya. Secara indah hal ini digambarkan oleh Alquran dalam bentuk do'a-do'a orang tua. Allah berfirman:

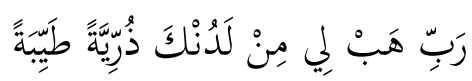

Ya Tuhanku, berilah aku dari sisi Engkau seorang anak yang baik (Q.S. Ali 'Imrân [3]: 38)

Do'a setiap muslim hendaklah menginginkan anak yang baik atau dzurriyyatan thayyibatan. Kata dzurriyyatan thayyibatan (anak yang baik) menurut berbagai ulama tafsir diartikan dengan anak yang shaleh. Diantaranya dalam tafsir al-Kasyfu wa al-Bayân dijelaskan bahwa dzurriyyatan thayyibatan (anak yang baik) adalah keturunan yang shaleh, bertakwa, menyenangkan dan diberkahi (Tafsir al-Kasyfu wa al-Bayan, t.th: 59). Tafsir yang senada juga terdapat dalam Tafsîr Tsa'labî bahwa anak yang baik adalah keturunan yang bertakwa lagi shaleh (al Tsa'labi t.th., 416). Sedangkan dalam tafsirtafsir lain, anak yang baik ditafsirkan sebagai anak yang shaleh.

Kehadiran anak yang shaleh sangat diidam-idamkan oleh pasangan suami istri karena selain dapat berbakti kepada kedua orang tua, do'a anak yang shaleh juga diijabah oleh AllahSwt.

Karena begitu pentingnya arti anak bagi hidup manusia, anak digambarkan sebagai perhiasan kehidupan dunia Allah berfirman:

$$
\text { الْمَالُ وَالْبَنُونَ زِينَةُ الحَيَاةِ الدُّنْيَا }
$$

Harta dan anak-anak adalah perhiasan kehidupan dunia (Q.S. al-Kahfi [18]: 46)

Perhiasan kehidupan ini merupakan hal yang dinanti-nanti oleh pasangan suami istri, ia merupakan berita yang menggembirakan bagi kedua orang tuanya.

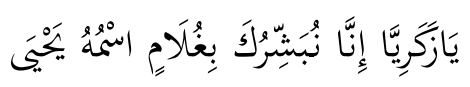

Hai Zakaria, sesungguhnya Kami memberi kabar gembira kepadamu akan (beroleh) seorang anak yang bernama Yahya. (Q.S. Maryam [19]:7) 
Kedudukan anak sebagai perhiasan kehidupan dunia bagi orang tua kadang-kadang hanya untuk dibangga-banggakannya. Oleh sebab itu Allah juga menjelaskan dalam Alquran bahwa anak juga merupakan cobaan. Allah berfirman:

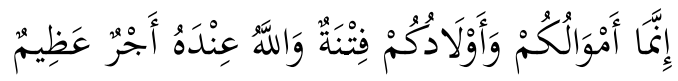

Sesungguhmya hartamu dan anak-anakmu hanyalah cobaan (bagimu), dan di sisi Allah-lah pahala yang besar. (Q.S. at-Taghâbun [64]: 15)

Dalam kedudukannya sebagai cobaan, kehadiran anak menguji orang tua mereka, apakah mereka mampu merawat, mengasuh dan mendidiknya, sehingga anak tersebut tumbuh dan berkembang sebagai pelanjut keturunan yang baik atau lebih khusus lagi menjadi anak yang shaleh yang selalu mendo'akan orang tuanya meskipun mereka sudah meninggal dunia.

Kehidupan adalah anugerah Allah Swt oleh sebab itu setiap jiwa harus dihormati dan karena itu tidak seorangpun boleh merampas hak hidup seorang anak apapun alasanya. Sehubungan dengan hak hidup, Allah Swt juga melarang pembunuhan terhadap anak. Sampai Allah Swt menyatakan bahwa ia telah menjamin rezeki anak dan orang tuanya.

Allah berfirman:

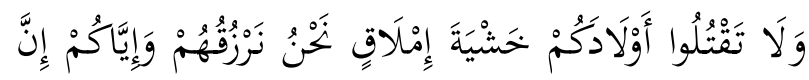

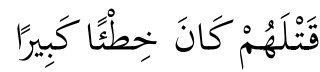

Dan janganlah kamu membunuh anak-anakmu Karena takut kemiskinan. Kamilah yang akan memberi rezki kepada mereka dan juga kepadamu. Sesungguhnya membunuh mereka adalah suatu dosa yang besar. (Q.S. al-Isrâ' [17]: 31).

Ayat di atas menegaskan tentang hak kelangsungan hidup bagi setiap anak yang lahir. Dalam rangka menunjang kelangsungan hidup tersebut, agama Islam menggariskan tentang berbagai kewajiban orang tua yang harus dipenuhi.

Pertama, kewajiban memberi nafkah. Islam memerintahkan setiap orang untuk memberikan nafkah kepada keluarga terdekatnya termasuk anak-anaknya. Allah berfirman:

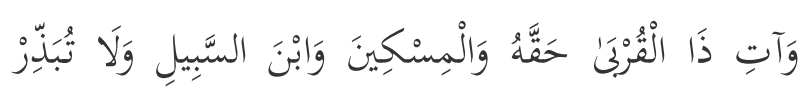

$$
\text { تَبِْْيرًا }
$$

Dan berikanlah kepada keluarga-keluarga yang dekat akan haknya, (Q.S. al Isrâ' [17]: 26)

Kedua, kewajiban untuk memelihara anak, terutama dalam bentuk pendidikan dan bimbingan, agar mereka terlindung dari hal-hal yang menjerumuskan mereka kepada kemungkaran. Allah berfirman:

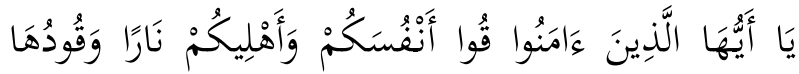

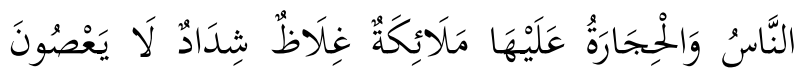

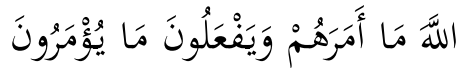

Hai orang-orang yang beriman, peliharalah dirimu dan keluargamu dari api neraka yang bahan bakarnya adalah manusia dan batu; penjaganya malaikat-malaikat yang kasar, keras, dan tidak mendurhakai Allah terhadap apa yang diperintahkan-Nya kepada mereka dan selalu mengerjakan apa yang diperintahkan. (Q.S. atTahrîm [66]: 6)

Dalam rangka memelihara diri dan keluarga yang dimaksud oleh ayat di atas, tentulah tercakup tentang kewajiban memberikan pendidikan jasmani maupun rohani. Hal itu bisa kita pahami dari sabda Nabi Muhammad Saw.:

$$
\text { وأحسنوا أدبهم (رواه ابن ماجه) رلى الله عليه و سلم أكرموا أولادكم }
$$


Rasulullah Saw. bersabda : "Muliakanlah anak anakmu dan baguskanlah pendidikanya" (H.R. Ibn Mâjah)

Ketiga, kewajiban berlaku adil terhadap anak. Orang tua wajib berlaku adil bagi anakanaknya. Sebab setiap anak mempunyai kedudukan yang sama. Nabi bersabda:

$$
\text { اتقو الله واعد لوا بين اولا دكم ( روه المسلم) }
$$

Bertakwalah kepada Allah dan berlaku adillah di antara anak-anakmu (H.R. Muslim)

Perlakuan yang tidak adil akan menimbulkan perasaan dianakemaskan dan dianaktirikan di antara anak-anak. Keduaduanya membawa pengaruh yang negatif terhadap kehidupan keluarga dan khususnya terhadap perkembangan anak-anak.

Dalam muzakarah MUI yang bekerjasama dengan UNICEF (1988) menyebutkan bahwa hak-hak anak yaitu:

1. Hak untuk hidup;

Hal ini berarti mereka harus memperoleh perlindungan dari segala macam yang dapat mengancam kehidupanya.

2. Hak untuk memperoleh nafkah;

Hal ini berarti orang tua, keluarga, masyarakat dan pemerintah tidak boleh membiarkan anak-anak hidup terlantar dan tidak terurus.

3. Hak untuk memperoleh pemeliharaan;

Hal ini berarti bahwa anak harus dapat perawatan dan pendidikan sebaik-baiknya agar mereka tumbuh secara wajar dan mampu menjawab tantangan yang akan dihadapinya.

4. Hak untuk memperoleh perlakuan adil;

Hak untuk mendapat perlakuan adil hal ini berarti orang tua tidak boleh bersikap pilih kasih terhadap anak-anaknya.

Pemenuhan terhadap hak-hak itu merupakan salah satu faktor untuk kelangsungan hidup anak agar mereka dapat tumbuh dan berkembang dengan wajar.

\section{Tinjauan Hukum Pidana Islam Mengenai Kekerasan Fisik terhadap Anak}

Kekerasan fisik terhadap anak merupakan terminologi baru dalam hukum pidana Indonesia yang tidak dijumpai dalam KUHP, hal ini baru muncul dalam UU No. 23 tahun 2002 tentang Perlindungan Anak namun belum ditemukan defenisi tentang kekerasan terhadap anak tersebut. Defenisi kekerasan terhadap anak ini baru ditemukan setelah terjadi perubahan terhadap UU No. 23 tahun 2002 menjadi UU No. 35 tahun 2014 tentang perubahan UU No. 23 tahun 2002 tentang Perlindungan Anak.

Dalam Pasal 1 angka 15 (a) UU No. 35 tahun 2014 dijelaskan bahwa "kekerasan adalah setiap perbuatan terhadap anak yang berakibat timbulnya kesengsaraan atau penderitaan secara fisik, psikis, seksual, dan/atau penelantaran, termasuk ancaman untuk melakukan perbuatan, pemaksaan, atau perampasan kemerdekaan secara melawan hukum".

Dalam tindak pidana kekerasan fisik yang terdapat dalam Pasal 1 angka 15 (a) di atas terdapat beberapa unsur yaitu:

1. Setiap perbuatan terhadap anak.

2. Berakibat timbulnya kesengsaraan atau penderitaan fisik.

Melihat kedua unsur yang terdapat dalam tindak pidana kekerasan fisik terhadap anak di atas, maka kekerasan fisik terhadap anak dilarang dalam hukum pidana Islam karena hal tersebut bertentangan dengan konsep pemeliharaan diri (hifz an-nafs). Larangan ini sejalan dengan maqâshid syarî'ah yaitu untuk kemaslahatan dunia dan akhirat dengan memelihara lima unsur pokok dalam kehidupan manusia yaitu: agama, diri, akal, keturunan, dan harta.

Pada dasarnya, perbuatan-perbuatan yang dilarang dalam hukum pidana Islam diharamkan kepada semua orang secara umum. 
Meski demikian hukum pidana Islam melihat adanya pengecualian atas dasar ini, yaitu pembolehan sebagian perbuatan yang dilarang bagi orang-orang yang memiliki karakter khusus sebab kondisi seseorang dan keadaan masyarakat menuntut pembolehan ini. Juga karena orang-orang yang diperkenankan untuk melakukan perbuatan yang dilarang sebenarnya melakukannya untuk mencapai suatu tujuan dan beberapa tujuan Islam ('Abdul Qâdir 'Audah, 2002: 406), artinya perbuatan yang dikerjakan tetap dilarang tetapi tidak dijatuhi hukuman (Ahmad Hanafi, 1993: 209).

Adapun bentuk-bentuk keadaan yang dikecualikan dan membolehkan melakukan perbuatan yang terlarang bagi orang-orang yang memiliki karakter khusus sebab kondisi seseorang atau keadaan masyarakat yang menuntut adanya pembolehan ini sebagai berikut ('Abdul Qâdir'Audah, 2002: 406):

1. Dalam pembelaan syar' i.

2. Dalam mendidik.

3. Dalam pengobatan.

4. Dalam permainan kesatriaan.

5. Dalam halalnya jiwa, anggota badan dan harta seseorang.

6. Dalam hak dan kewajiban penguasa.

Hukum Islam melarang semua bentuk kekerasan fisik terhadap anak, akan tetapi dalam permasalahan tertentu dan dalam aturan tertentu diperbolehkan menggunakan tindakan $t a^{\prime} d i b$ (pengajaran) demi kemaslahatan anak untuk masa depan. Terdapat beberapa hadis mengenai hal ini yaitu:

1. Hadis yang diriwayatkan oleh Imam Abû Dawud Rasulullah menyampaikan:

$$
\begin{aligned}
& \text { عن عمرو بن شعيب عن أبيه عن جده قال قال رسول } \\
& \text { الله صلى الله عليه وسلم مروا أولادكم بالصلاة وهم } \\
& \text { أبناء سبع سنين واضربوهم عليها وهم أبناء عشر سنين } \\
& \text { وفرقوا بينهم في المضاجع (روه ابو دود) }
\end{aligned}
$$

Dari 'Umar bin Syu'aib dari ayahnya dari kakeknya berkata : Rasulullah SAW telah bersabda: "Suruhlah anak kalian shalat sejak usia 7 tahun dan pukullah ia apabila meninggalkan shalat bila telah berusia 10 tahun dan pisahkanlah tempat tidur mereka (antara laki-laki dan perempuan) masing-masing". (H.R. Abu Dawud).

2. Hadis yang diriwayatkan oleh Imam Turmidẑ, Ibnu Khuzaimah dan Darâmî sebagai berikut:

عن عمه عبد المالك بن الربيع بن سبرة ، عن أبيه ، عن

جده ، قال : قال رسول الله صلى الله عليه وسلم :

علموا الصبي الصلاة ابن سبع سنين واضربوه عليها ابن

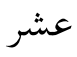

Dari ibunya 'Abdul Mâlik bin Rabî' bin Sabrah dari Ayahnya dari Kakeknya ia berkata, Telah bersabda Rasulullah Saw: "Ajarilah anak kalian shalat waktu berusia 7 tahun dan pukullah mereka apabila meninggalkan shalat sewaktu berusia 10 tahun." (H.R. Turmidzî, Ibn Khuzaimah).

3. Hadis yang diriwayatkan oleh Ahmad bin Hambal, sebagai berikut:

عن عمرو بن شعيب عن أبيه عن جده قال قال رسول

الله صلى الله عليه و سلم : مروا صبيانكم بالصلاة إذا

بلغوا سبعا واضربوهم عليها إذا بلغوا عشرا وفرقوا بينهم

$$
\text { في المضاجع }
$$

Dari Umar bin Syu'aib dari ayahnya dari kakeknya berkata: Rasulullah Saw telah bersabda : "Apabila usianya telah sampai tujuh tahun suruhlah anak-anak kalian shalat dan pukullah mereka apabila meninggalkan shalat bila telah berusia 10 tahun dan pisahkanlah mereka (antara laki-laki dan perempuan) di tempat tidurnya masingmasing". (H.R. Ahmad). 
4. Hadis yang diriwayatkan oleh Dâruqutnî dan Baihaqî, sebagai berikut:

$$
\text { حدثنا عمرو بن شعيب عن أبيه عن جده قال قال الله صلى الله عليه و سلم : مرو صبيانكم بالصالاة }
$$

Telah mengabarkan kepada kami Umar bin Syu'aib dari ayahnya dari kakeknya berkata: Rasulullah Saw telah bersabda: "Suruhlah anak kalian shalat di usia 7 tahun dan pukullah ia apabila meninggalkan shalat di usia 10 tahun dan pisahkan mereka di tempat tidurnya masing-masing". (H.R. Dâruqutnî dan Baihaqî).

5. Hadis yang diriwayatkan oleh Dâruqutnî:

$$
\text { عروهم أنس قال قال رسول الله صلى الله عليه و سلم : عشرة }
$$

Dari Anas yang telah berkata, Rasulullah Saw bersabda: "Suruhlah mereka shalat di umur 7 tahun dan pukullah mereka apabila meninggalkan shalat di umur 13 Tahun. (H.R. Dâruqutnî).

Syekh Jalaludin al-Mahali (t.th: 121) menyampaikan, apabila anak telah berumur 7 tahun maka orang tua sudah boleh memerintahkan anaknya shalat dan dipukul apabila ia berumur 10 tahun (apabila meninggalkannya). Memukul adalah kewajiban bagi para wali (ayah atau kakek atau orang yang telah diberi wasiat atau penanggung jawab) (Jalaluddîn al-Mahalî, t.th.: 121). Shalat merupakan kewajiban yang telah menjadi beban taklif bagi manusia yang telah dewasa (akil baligh), usia itu penulis perkirakan umur 10 tahun sesuai dengan Hadis, karena tidak mungkin hukum diterapkan pada anak yang belum dewasa. Rasulullah Saw bersabda:

$$
\begin{aligned}
& \text { رفع القلم عن ثلاثة عن المجنون المغلوب على عقله حتى } \\
& \text { يبرأ وعن النائم حتى يستيقظ وعن الصبى حتى يحتلم } \\
& \text { (أحمد، وأبو داود، والحاكم) }
\end{aligned}
$$

Pena diangkat dari tiga golongan: orang yang gila yang akalnya tertutup sampai sembuh orang yang tidur sehingga bangun dan anak kecil sehingga baligh (H.R. Ahmad, Abu Dawud, Hakim).

Pengajaran dalam bentuk pemukulan terhadap anak merupakan kewajiban dari para wali artinya pemukulan ini adalah pemukulan dalam konteks pendidikan bukan penyiksaan. Pemukulan ini adalah hukuman yang bersifat mendidik bagi anak yang tidak mau melaksanakan kewajibannya. Kewajiban anak ini diatur dalam Pasal 19 UU No. 23 Tahun 2002, bahwa anak berkewajiban untuk:

1. Menghormati orang tua, wali, dan guru;

2. Mencintai keluarga, masyarakat, dan menyayangi teman;

3. Mencintai tanah air, bangsa, dan negara;

4. Menunaikan ibadah sesuai dengan ajaran agamanya; dan

5. Melaksanakan etika dan akhlak yang mulia.

Praktisi hukum Hasan al-'Asymâwî mengatakan: pengunaan hukuman itu diperbolehkan ketika anak-anak kita tidak peduli dan tidak respon terhadap perasaan dan hak-hak orang lain. Jika hukuman memang diperlukan, hendaknya kita ketahui bahwa dalam pemberian hukuman itu ada tahap-tahapannya, tidak boleh menempuh hukuman yang lain kecuali hukuman yang kita diberikan benar-benar sesuai. Terkadang melihat anak dengan rasa tidak senang, bagi anak (bahasa tubuh) sudah cukup, atau penolakan terhadap sikap mereka mungkin sudah cukup dan terakhir dengan cara memukul mereka. Memukul anak merupakan hal yang perlu jika semua hukuman tidak digubris dan semuanya telah berlalu tanpa memberikan efek jera. Memukul anak sebagai sebuah hukuman harus diletakkan dalam konteks seperti 
larangan-larangan yang lain. Menggunakannya boleh ditempuh jika itu perlu (darûrî), yaitu dengan cara hati-hati dan penuh kesabaran (Muhammad Nabîl Kâdzim, 2009: 20).

Oleh karena itu, menghukum anak bertujuan untuk mendidik anak. Adapun syaratsyarat dalam mendidik anak sebagaimana yang dijelaskan oleh 'Abdul Qâdir 'Audah (t.th.: 446):

1. Pendidikan wajib diberikan kepada anak kecil atas kesalahan yang telah dilakukannya, bukan atas kesalahan yang dikhawatirkan dilakukannya,

2. Pemukulan terhadap anak kecil juga tidak sampai melukainya, namun disesuaikan pada keadaan dan usianya,

3. Tidak pada muka dan tempat-tempat yang dikhawatirkan rawan seperti perut dan kepala,

4. Harus dengan maksud pendidikan dan tidak berlebih-lebihan,

5. Harus dianggap sebagai pendidikan untuk anak-anak.

Memukul anak dalam hukum pidana Islam merupakan hal yang dilegalkan dalam konteks mendidik. Dalam buku as-syibhan karangan Syaikh Syamsuddîn al-Ambâbî menyebutkan tentang tata cara memukul anak yang benar (syarat-syarat memukul):

1. Memukul harus dilakukan berselang-seling

2. Harus diberikan jarak antara dua pukulan, sedangkan jeda waktu itu sekiranya efek pukulan pertama telah berkurang,

3. Dalam memukul tidak boleh mengangkat siku, supaya efek sakit yang ditimbulkan tidak berbahaya,

4. Seorang pengasuh tidak boleh memukul ketika ia sedang marah,

5. Urungkan niat untuk memukul anak ketika dia menyebut nama Allah,

6. Tidak boleh memukul anak kecuali ia tersebut berusia 10 tahun.

Menurut pendapat Imâm Mâlik dan Imâm Ahmad bin Hambal orang yang memukul tidak bertanggung jawab selama pemukulan tersebut pantas dianggap sebagai pendidikan dan berada dalam batas-batas yang dibolehkan. Adapun jika pemukulan tersebut dengan keras dan tidak dianggap sebagai pendidikan, orang yang memukul harus mempertanggungjawabkan perbuatannya tersebut secara pidana. ('Abdul Qâdir'Audah, t.th.: 446).

Imâm Syâfi'î berpendapat bahwa pendidik bertanggung jawab atas kerusakan tubuh anak dan kerusakan sebahagian anggota tubuhnya pada semua keadaan karena pendidikan adalah haknya, bukan kewajibannya. Karena ia berhak membiarkan atau melakukannya. Jika dia menggunakan hak tersebut, ia harus bertanggung jawab atas akibat dari tindakannya. ('Abdul Qâdir'Audah, t.th.: 447).

Adapun Imâm Abû Hanîfah secara pribadi berpendapat bahwa ayah, kakek dan orang yang diserahi wasiat atas anak kecil bertanggung jawab atas kerusakan tubuh anak atau kerusakan sebagian anggota tubuhnya, sebagaimana suami bertanggung jawab pada istrinya. ('Abdul Qâdir 'Audah, t.th: 447).

Jelaslah bahwa Imam Mujtahid yang empat telah bersepakat bahwa setiap orang yang melakukan pengajaran yang bersifat menganiaya (kekerasan fisik) harus mempertanggung jawabkan perbuatannya secara hukum.

Dari uraian di atas, dapat dipahami bahwa hukum pidana Islam membenarkan pengajaran walaupun dalam bentuk pemukulan asalkan tidak dalam konteks penganiayaan yang berakibat kesengsaraan atau penderitaan bagi anak. Akan tetapi jika terlepas dari ketentuan yang telah diuraikan di atas maka kekerasan tersebut termasuk tindak pidana penganiayaan dalam hukum pidana Islam. Hal inilah yang disebutkan dalam UU No. 35 Tahun 2014 Pasal 54:

(1) Anak di dalam dan di lingkungan satuan pendidikan wajib mendapatkan perlindungan dari tindak kekerasan fisik, psikis, kejahatan seksual, dan kejahatan 
lainnya yang dilakukan oleh pendidik, tenaga kependidikan, sesama peserta didik, dan/atau pihak lain.

(2) Perlindungan sebagaimana dimaksud pada ayat (1) dilakukan oleh pendidik, tenaga kependidikan, aparat pemerintah, dan/atau Masyarakat.

Dari penjelasan di atas dapat disimpulkan bahwa tindak pidana kekerasan terhadap anak merupakan tindak pidana dan dilarang dalam hukum pidana Islam. Akan tetapi pertanggung jawaban pidana hapus jika ada sebuah kemaslahatan yang lebih penting. Seperti halnya dalam mendidik. Ajaran Islam memperbolehkan memukul dalam mendidik tentunya berdasarkan ketentuan yang telah ditetapkan. Jika kekerasan fisik terhadap anak keluar dari ketentuan yang telah ditetapkan dalam hukum Islam, maka hal ini tergolong kepada tindak pidana penganiayaan terhadap anak. Adapun hukuman bagi pelaku tindak pidana kekerasan terhadap anak ini sama halnya dengan hukuman bagi pelaku tindak pidana penganiayaan dalam hukum pidana Islam.

\section{Pandangan Hukum Pidana Islam Mengenai Sanksi bagi Pelaku Tindak Pidana Kekerasan Fisik terhadap Anak}

Sebelum melihat bagaimana pandangan hukum Islam mengenai sanksi bagi pelaku kekerasan fisik terhadap anak terlebih dahulu akan diuraikan Undang-undang yang mengatur sanksi hukum bagi pelaku tindak kekerasan terhadap anak.

Terdapat dalam UU No. 35 Tahun 2014 diatur dalam Pasal 76 C, yaitu:

1. Pasal76C;

Setiap orang dilarang menempatkan, membiarkan, melakukan, menyuruh melakukan, atau turut serta melakukan kekerasan terhadap Anak

2. Pasal 80;
(1) Setiap orang yang melanggar ketentuan sebagaimana dimaksud dalam Pasal 76 C, dipidana dengan pidana penjara paling lama 3 (tiga) tahun 6 (enam) bulan dan/atau denda paling banyak Rp. 72.000.000,00 (tujuh puluh dua juta rupiah).

(2) Dalam hal anak sebagaimana dimaksud pada ayat (1) luka berat, maka pelaku dipidana dengan pidana penjara paling lama 5 (lima) tahun dan/atau denda paling banyak Rp. 100.000.000,00 (seratus juta rupiah).

(3) Dalam hal Anak sebagaimana dimaksud pada ayat (2) mati, maka pelaku dipidana dengan pidana penjara paling lama 15 (lima belas) tahun dan/atau denda paling banyak Rp. 3.000.000.000,00 (tiga miliar rupiah).

(4) Pidana ditambah sepertiga dari ketentuan sebagaimana dimaksud pada ayat (1), ayat (2), dan ayat (3) apabila yang melakukan penganiayaan tersebut Orang Tuanya.

Undang-Undang di atas menyebutkan bahwa hukuman bagi pelaku kekerasan fisik terhadap anak adalah hukuman penjara dan denda.

Dalam pidana hukum Islam, tindak pidana kekerasan fisik terhadap anak ini bisa tergolong pada tindak pidana penganiayaan karena mengakibatkan kerusakan bagi tubuh anak juga bisa tergolong tindak pidana pembunuhan jika kekerasan tersebut mengakibatkan hilangnya nyawa anak.

Menurut para fuqahấ tindak pidana penganiayaan adalah setiap perbuatan yang menyakitkan mengenai badan seseorang namun tidak mengakibatkan kematian. Ini pendapat yang sangat teliti dan mampu memuat setiap bentuk melawan hukum dan kejahatan yang bisa digambarkan, sehingga masuk di dalamnya: melukai, memukul, mendorong, menarik, memeras, menekan, memotong rambut, 
mencabut rambut dan lain-lain. ("Abdul Qâdir 'Audah, t.th.: 180).

Tindak pidana penganiayaan ini terbagi menjadi tindak pidana penganiayaan sengaja dan tidak sengaja. Penganiayaan sengaja adalah perbuatan yang dilakukan pelaku secara sengaja dengan maksud melawan hukum. Misalnya: seorang guru yang memukul muridnya dengan tujuan menganiaya muridnya. Adapun tindak pidana penganiayaan yang tidak sengaja yaitu perbuatan yang dilakukan pelaku tanpa ada niat untuk melawan hukum. Misalnya : seorang melempar batu tanpa ia sadari batu tersebut mengenai anak kecil.

Adapun hukuman bagi tindak penganiayaan sengaja dibagi menjadi dua yaitu hukuman pokok dan hukuman pengganti. Adapun hukuman pokoknya adalah qisâsh dan hukuman penggantinya adalah diyat dan takzîr.

Qisâsh adalah hukuman pokok untuk tindak pidana penganiayaan disengaja sedangkan diyat dan takzîr adalah hukuman pengganti yang menempati posisi qisâsh. (Ahmad Wardi Muslich, 2005: 185). Untuk tindak pidana penganiayaan tidak sengaja hukuman pokoknya adalah diyat atau denda, yaitu satu-satunya hukuman pokok dan tidak ada hukuman pengganti yang sesuai untuk diyat. Akan tetapi apabila lembaga peradilan menghendaki untuk menjadikan hukuman tindak pidana ini dengan takzîr sebagai hukuman pokok ataupun pengganti tidak ada nash agama yang melarangnya. (Ahmad Wardi Muslich, 2005: 225).

Hukum Islam menjatuhkan hukuman qisâsh bagi pelaku tindak pidana penganiayaan. Adapun qisâsh itu sendiri adalah menghukum pelaku sama seperti apa yang telah ia lakukan terhadap korban. Jika pelaku melakukan kekerasan fisik terhadap anak hingga anak tersebut luka atau patah tulang maka pelaku juga harus dilukai atau dipatahkan tulangnya. Apabila kekerasan terhadap anak tersebut sampai menghilangkan nyawa anak maka pelaku juga harus dibunuh.

Adapun sumber hukum Islam mengenai qisâsh sebagai hukuman pokok tindak pidana penganiayaan sengaja adalah Alquran surat alBaqarah ayat 178-179, sebagai berikut.

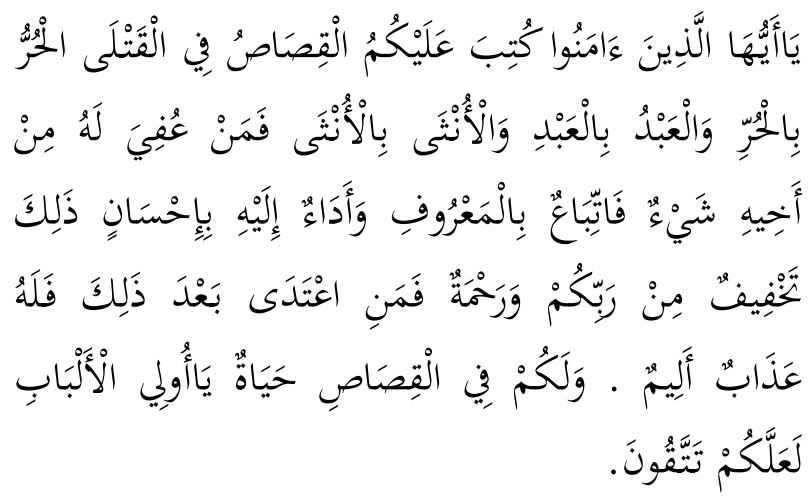

Hai orang-orang yang beriman, diwajibkan atas kamu qishaash berkenaan dengan orangorang yang dibunuh; orang merdeka dengan orang merdeka, hamba dengan hamba, dan wanita dengan wanita. Maka Barang siapa yang mendapat suatu pema'afan dari saudaranya, hendaklah (yang mema'afkan) mengikuti dengan cara yang baik, dan hendaklah (yang diberi ma'af) membayar (diat) kepada yang memberi ma'af dengan cara yang baik (pula). yang demikian itu adalah suatu keringanan dari Tuhan kamu dan suatu rahmat. Barang siapa yang melampaui batas sesudah itu, Maka baginya siksa yang sangat pedih. Dan dalam qishaash itu ada (jaminan kelangsungan) hidup bagimu, Hai orangorang yang berakal, supaya kamu bertakwa. (Q.S. al-Baqarah [2]: 178-179)

Ayat ini menjelaskan tentang keharusan bagi penguasa memberlakukan hukuman qisâsh atas para pelaku tindak pembunuhan. Yaitu apabila seseorang melakukan tindak pembunuhan terhadap orang lain maka ia harus dibunuh pula. Ungkapan في القتل dalam ayat ini tidaklah menunjukkan kepada kekhususan. Artinya hukuman qisâsh tidak hanya dijatuhkan pada pelaku tindak pidana pembunuhan saja, 
tetapi juga diberlakukan pada pelaku tindak pidana penganiayaan lainnya secara fisik, seperti melukai atau memotong anggora tubuh. (Kadar M. Yusuf, 2011: 318). Dalam alquran surat alMaidah ayat 45 ditegaskan:

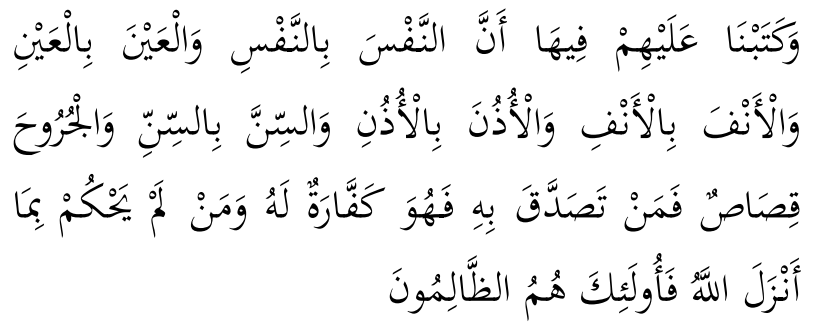

Dan Kami telah tetapkan terhadap mereka di dalamnya (At Taurat) bahwasanya jiwa (dibalas) dengan jiwa, mata dengan mata, hidung dengan hidung, telinga dengan telinga, gigi dengan gigi, dan luka luka (pun) ada kisasnya. Barang siapa yang melepaskan (hak kisas)-nya, Maka melepaskan hak itu (menjadi) penebus dosa baginya. Barang siapa tidak memutuskan perkara menurut apa yang diturunkan Allah, Maka mereka itu adalah orang-orang yang zalim. (Q.S. al-Maidah [5]: 45).

Qisâsh adalah hukuman yang paling adil dalam penjatuhan hukuman di atas muka bumi ini, baik masa dahulu maupun masa sekarang. Karena pelaku dihukum sesuai dengan apa yang dilakukannya. Qisash adalah hukuman terbaik untuk melindungi masyarakat dari tindakantindakan kriminal, karena pelaku kriminal sendiri akan berpikir ke belakang artinya apabila ia melakukan kejahatan pada diri orang lain ia akan menanggung akibat yang serupa bagi dirinya sendiri.

Pada dasarnya seseorang dengan berani melakukan kekerasan fisik terhadap anak karena ia menganggap anak kecil tersebut tidak akan memberikan balasan kepadanya. Akibat dari hal ini ia tidak akan takut dan segan-segan untuk melakukan tindak kekerasan fisik terhadap anak. Sebaliknya pelaku akan takut bila seandainya ia akan mendapat perlawanan dari anak kecil apalagi perlawanan yang setimpal. Contoh, apabila seseorang akan melakukan kekerasan fisik terhadap anak kecil dengan pisau ternyata anak tersebut juga memiliki pisau yang akan membalas, maka ia tentunya akan mengurungkan niatnya karena ia tahu bahwa anak kecil itu juga akan melukai, menyayat bahkan membunuh dirinya.

Qisâsh sebagai hukuman pokok ini bisa terhalang dan akhirnya hukuman inipun tidak diterapkan karena beberapa sebab. Sebab terhalang qisâsh ini terbagi menjadi dua yaitu sebab umum dan sebab khusus (lbnu Rusyd, t.th: 304). Adapun sebab umum qisash menjadi terhalang yaitu pertama, korban bagian dari pelaku, jika korban bagian dari pelaku maka qisash terhalang, korban termasuk bagian dari pelaku jika korban adalah anak dari pelaku. Kedua, tidak ada kesetaraan antara korban dan pelaku sehingga tidak ada hukuman qisash. Ketiga, perbuatan harus menyerupai disengaja. Keempat, tindak pidana terjadi di Dar al-Harb (negara non muslim). Kelima, perbuatan dilakukan secara tidak langsung. Keenam, qisash tidak mungkin dilaksanakan. (Ahmad Wardi Muchlis, 2005: 186-188).

Qisâsh pada tindak pidana penganiayaan bisa gugur oleh tiga faktor yang pertama yaitu, hilangnya tempat qisâsh, kedua, adanya pengampunan dan ketiga, adanya akad damai. ('Abdul Qâdir'Audah, t.th.: 226).

Dalam hukuman qisâsh korban diberi wewenang untuk mengampuni hukuman qisâsh, dengan memaafkan, maka gugurlah hukuman qisâsh tersebut. Korban memiliki hak untuk meminta ganti rugi berupa diyat kepada pelaku. Apabila pemaafan ini secara cuma-cuma maka pelaku tetap dikenai hukuman yaitu berupa hukuman takzîr dari pemerintah.

Kedua hukuman diyat. Hukuman diyat merupakan hukuman pengganti pada tindak pidana pembunuhan dan penganiayaan sengaja serta hukuman pokok pada tindak pidana pembunuhan dan penganiayaan tidak sengaja. 
Adapun dalil Alquran mengenai diyat sebagai hukuman pengganti adalah surat al-Baqarah ayat 178 :

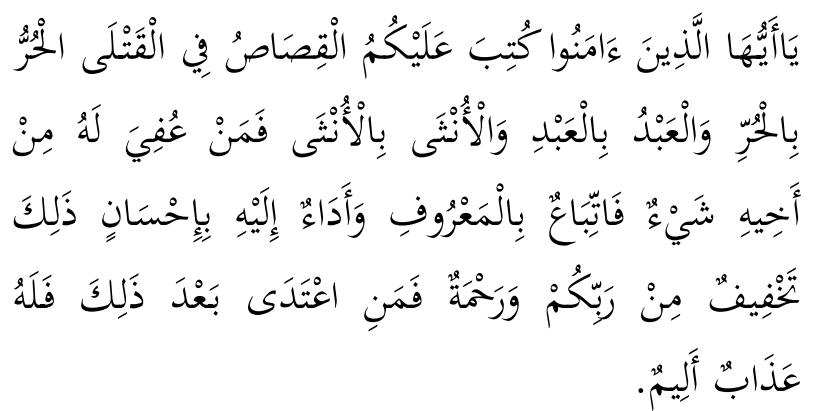

Hai orang-orang yang beriman, diwajibkan atas kamu qishash berkenaan dengan orangorang yang dibunuh; orang merdeka dengan orang merdeka, hamba dengan hamba, dan wanita dengan wanita. Maka Barang siapa yang mendapat suatu pema'afan dari saudaranya, hendaklah (yang mema'afkan) mengikuti dengan cara yang baik, dan hendaklah (yang diberi ma'af) membayar (diat) kepada yang memberi ma' af dengan cara yang baik (pula). yang demikian itu adalah suatu keringanan dari Tuhan kamu dan suatu rahmat. Barang siapa yang melampaui batas sesudah itu, Maka baginya siksa yang sangat pedih. (Q.S. al-Baqarah [2]: 178)

Diyat merupakan hukuman pokok pada tindak pidana pembunuhan dan penganiayaan tidak disengaja. Adapun dasar penetapan hal ini adalah Alquran surat an-Nisa' ayat 92:

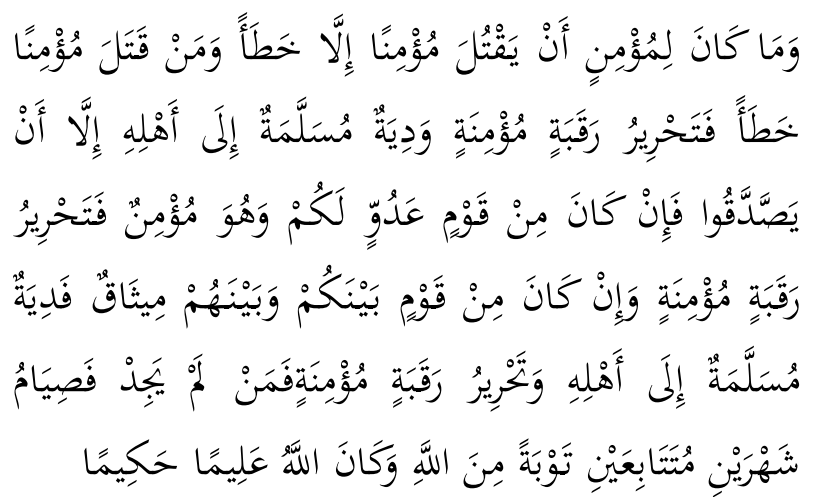

Dan tidak layak bagi seorang mukmin membunuh seorang mukmin (yang lain), kecuali karena tersalah (tidak sengaja), dan
Barang siapa membunuh seorang mukmin karena tersalah (hendaklah) ia memerdekakan seorang hamba sahaya yang beriman serta membayar diat yang diserahkan kepada keluarganya (si terbunuh itu), kecuali jika mereka (keluarga terbunuh) bersedekah. Jika ia (si terbunuh) dari kaum (kafir) yang ada Perjanjian (damai) antara mereka dengan kamu, maka (hendaklah si pembunuh) membayar diat yang diserahkan kepada keluarganya (si terbunuh) serta memerdekakan hamba sahaya yang beriman. Barang siapa yang tidak memperolehmya, maka hendaklah ia (si pembunuh) berpuasa dua bulan berturut-turut untuk penerimaan taubat dari pada Allah dan adalah Allah Maha mengetahui lagi Maha Bijaksana. (Q.S. anNisa' [4]: 92)

Diyat baik sebagai hukuman pokok maupun hukuman pengganti, jika dimutlakan berarti diyat sempurna yaitu seratus ekor unta. Adapun diyat yang kurang dari diyat sempurna disebut dengan arsy atau denda. Akan tetapi banyak fuqahâ' yang memakai kata diyat pada arsy. Arsy ini terbagi kepada dua macam yaitu, arsy yang telah ditentukan dan arsy yang belum ditentukan. Arsy yang telah ditentukan adalah arsy yang telah ditetapkan kadarnya oleh Allah, seperti tangan dan kaki. Adapun arsy yang belum ditentukan adalah arsy yang tidak ada nash dan ketentuannya diserahkan kepada hakim ini yang disebut arsy hukum atau kebijakan. ('AbdulQâdir'Audah, t.th:: 1, 230).

Ketiga hukum takzîr. Imam Malik meletakkan hukuman takzîr sebagai hukuman pokok pada tindak penganiayaan disengaja. Imam Malik berpendapat bahwa pelaku tindak pidana penganiayaan secara disengaja berhak ditakzîr, baik ia berhak diqisâsh maupun tidak, karena adanya penghalang qisâsh syubhat, ampunan atau akad damai. Imam Abu Hanifah, Imam Syafi'i dan Ahmad bin Hambal berpendapat tidak ada takzîr bersama dengan qisâsh. Karena Allah berfirman, dan luka-luka 
pun ada qisâshnya ( 'Abdul Qâdir 'Audah, t.th.: 229).

Jika ketiga Imam tidak sepakat menjadikan takzîr sebagai hukuman pokok, bukan berarti mereka menghalangi takzîr sebagai hukuman pengganti ketika qisâsh gugur atau terhambat berbagai sebab jika wali melihat itu perlu. Karena itu pelaku berhak di takzîr, baik posisi qisâsh telah diganti diyat maupun diyatnya sudah diampuni. Adapun ketentuan takzîr dan macamnya diserahkan kepada pemerintah yang akan memilih jenis hukuman dan kadarnya atau diserahkan kepada hakim untuk memilih hukuman di antara jenis hukuman takzîr yang telah ditentukan.

Sebagaimana yang terdapat dalam UU No. 35 Tahun 2014 pelaku tindak pidana kekerasan fisik terhadap anak akan dijatuhi hukuman penjara. Dalam hukum Islam penjara termasuk hukuman $t a^{\prime} z \hat{i} r$. Maksud utama sanksi $t a^{\prime} z \hat{\imath} r$ adalah sebagai preventif dan represif serta kuratif dan edukatif. Yang dimaksud dengan fungsi preventif adalah bahwa sanksi $t a^{\prime} z \hat{\imath} r$ harus memberikan dampak positif bagi orang lain (orang yang tidak dikenai hukuman $t a^{\prime} z \hat{\imath} r$ ), sehingga orang lain tidak melakukan perbuatan yang sama dengan terhukum. Yang dimaksud dengan fungsi represif adalah bahwa sanksi $t a^{\prime} z \hat{\imath} r$ harus membawa dampak positif bagi si terhukum, sehingga ia tidak melakukan perbuatan yang menyebabkan dirinya dijatuhi hukuman ta'zîr (Djazuli, 1997: 186-187).

Yang dimaksud dengan fungsi kuratif adalah bahwa ta'zîr itu mampu membawa perbaikan sikap dan perilaku terhukum dikemudian hari. Yang dimaksud fungsi edukatif ialah sanksi $t a^{\prime} z \hat{\imath} r$ harus mampu menumbuhkan hasrat terhukum untuk mengobah pola hidupnya sehingga ia akan menjahui perbuatan maksiat bukan karena takut hukuman melainkan semata-mata karena tidak senang pada kejahatan (Djazuli, 1997: 186-187).

Dalam UU No. 35 Tahun 2014 tidak ditemukan sanksi hukuman qisâsh, oleh sebab itu penjatuhan sanksinya berbentuk penjara dan denda seperti yang terdapat dalam Pasal 80 UU No.35Tahun 2014.

Penjatuhan hukuman penjara ini dalam hukum Islam merupakan sebuah bentuk hukuman $t a^{\prime} z \hat{\imath} r$. Akan tetapi $t a^{\prime} z \hat{\imath} r$ dalam hukum Islam mengenai tindak pidana kekerasan fisik hanya menempati hukuman pengganti. Imam Malik menyatakan bahwa ta'zîr menempati hukuman pokok maka harus dibarengi dengan hukuman pokok lainnya.

Adapun hukuman denda yang terdapat dalam UU No. 35 Tahun 2014 juga terdapat dalam hukum pidana Islam dikenal dengan istilah diyat. Akan tetapi hukuman denda ini menempati hukuman pokok pada tindak pidana penganiayaan tidak sengaja dan menempati hukuman pengganti pada tindak pidana penganiayaan sengaja.

Dalam masalah denda hukum Islam menyerahkan denda yang didapat dari pelaku kepada korban bukan kepada negara seperti halnya hukum positif. Dari sini terlihat jelas bahwa Islam sangat mengutamakan asas kemanfaatan hukum, karena denda tersebut berhak didapat oleh korban sebagai ganti rugi atas pengerusakan yang telah dilakukan pelaku.

Selain memperhatikan asas kemanfaatan hukum, Islam juga memperhatikan asas keadilan. Asas keadilan akan didapat melalui hukuman qisash, karena qisash merupakan bentuk hukuman yang setimpal. Selain asas keadilan dan kemanfaatan hukum, Islam menyempurnakannya dengan memperhatikan asas kepastian hukum. Kepastian hukum didapat dari adanya hukuman pokok, pengganti dan tambahan dalam Islam. Berbeda halnya dengan hukum positif, jika hukum positif menyerahkan sepenuhnya penentuan hukuman oleh hakim melalui Undang-undang tetapi hukum Islam menyerahkan sepenuhnya penentuan hukuman oleh pihak korban agar kepastian hukum terlaksana. 
Melalui penentuan hukum oleh pihak korban maka di sana akan bergabung ketiga asas sekaligus yaitu asas kepastian hukum, asas keadilan dan asas kemanfaatan.

Dalam pasal 80 ayat 4 UU No. 35 tahun 2014, terdapat penambahan hukum sepertiga apabila yang melakukan kekerasan tersebut adalah orang tua anak. Penambahan hukuman ini berbeda halnya dengan hukum Islam karena hukum Islam justru meringankan hukuman bagi orang tua apabila melakukan kekerasan terhadap anaknya.

Keringanan hukuman ini berpatokan dari dalil aqli maupun naqli. Secara rasional apabila orang tua diperberat hukumannya menjadi sepertiga maka yang akan menderita kerugian itu sendiri adalah anak. Selain alasan tersebut secara rasional juga tidak akan mungkin dengan sengaja orang tua mau menyakiti atau membunuh anaknya sendiri.

Dalam Hadis Rasulullah Saw bersabda :

$$
\begin{aligned}
& \text { حدثنا أبو سعيد الأشج حدثنا الأحمر عن الحجاج بن } \\
& \text { أرطأة عن عمرو بن شعيب عن ابيه عن عمر بن } \\
& \text { الخطاب قال : سمعت رسول الله صلى الله عليه و سلم } \\
& \text { يقول لا يقاد الوالد بالولد }
\end{aligned}
$$

Mengabarkan pada kami Abu Sa'id al-Asyaj mengabarkan pada kami Ahmar dari Hujaj bin Arith'ah dari 'Umar bin Syu'aib dari Ayahnya dati Umar bin Khathab berkata: aku mendengan Rasulullah Saw. bersabda: "Tidak diqishash orang tua yang membunuh anaknya" berkata syekh al-Abani Hadis shahih. (H.R. Turmidzi)

Akhirnya penulis berpendapat bahwa sanksi hukuman bagi pelaku tindak kekerasan fisik terhadap anak yang terdapat dalam UU No. 35 tahun 2014, dari segi hukumannya ada yang dibenarkan dalam hukum Islam yaitu hukuman $t a^{\prime} z \hat{\imath} r$ dan diyat akan tetapi aplikasinya masih berbeda dengan hukum Islam. Adapun dari segi tujuan penghukuman untuk menjerakan dan mendidik pelaku ini sama halnya dengan tujuan hukum Islam.

\section{PENUTUP}

Berdasarkan uraian di atas, penulis mengambil kesimpulan bahwa sebagai larangan kekerasan fisik terhadap anak yang terdapat dalam UU No. 35 Tahun 2014 dengan hukum pidana Islam demi terwujudnya pemeliharaan diri. Akan tetapi kekerasan fisik yang terdapat dalam pengajaran diperbolehkan dalam hukum Islam, tentunya sesuai dengan ketentuan yang telah ditetapkan. Adapun mengenai sanksi bagi pelaku tindak kekerasan fisik terhadap anak yang terdapat dalam UU No. 35 tahun 2014 yaitu hukuman penjara dan denda dibenarkan dalam hukum pidana Islam. Penjara dan denda sama halnya dengan sanksi ta'zîr dan diyat yang dipakai dalam tindak pidana penganiayaan dan pembunuhan. Akan tetapi aplikasinya masih berbeda dengan hukum Islam. Dalam tindak pidana kekerasan fisik yang disengaja, hukum Islam memakai sanksi penjara dan denda sebagai hukuman pengganti sedangkan pada tindak pidana kekerasan fisik yang tidak disengaja penjara dan denda merupakan hukuman pokok.

\section{DAFTAR KEPUSTAKAAN}

'Audah. Abdul Qâdir, t.th. at-Tasyî' al-Jinâî bi al-Islâmî Muqâranan bi al-Qânûn alWadh'î, Beirût : Dâr al-Kitâb al-'Arabî,.

Abû 'Abdillâh al-Quzwînî. Muhammad bin Yazîd, t.th. Sunan Ibn Mâjah, Beirût : Dâr al-Fikr.

Abû 'Abdillâh as-Syaibanî. Ahmad bin Hambal, t.th. Musnad Ahmad bin Hambal, Kairo : Mu'sasah Qurtubah.

Abû al-Husein Muslim bin Hujâj bin Muslim al-Qusyarî al-Naisâbûrî selanjutnya 
dikenal dengan Imam Muslim, t.th. alJâmi' as-Shahîh al-Musamma Shahîh Muslim, Beirût : Dâr al-Faq al-Jadîdah.

Abu 'Îsya at-Turmidzî as-Salmî. Muhammad bin 'îsya, t.th. Sunan Turmidzî, Beirût : Dâr ihyấ' at-Turâs al-'Arabî.

Abû Dawud Sulaimân. Ibn al-Sajtânî. Imâm Hâfiz, 2005 M/ 1426H. Sunan Ab̂̀ Dâwud, Beirût: Dâr al Kitâb al-'Arabî.

Bahnasi. Ahmad Fathî, t.th. Madkhul al-Figh al-Jina'iy al-Islâmiy, Kairo: Dâr as-Syurûq.

Al-Baihaqî. Abû Bakar Ahmad bin Husain bin 'Alî, $1344 \mathrm{H}$. as-Sunan al-Kubrâ Li al-Baihaqî , Majlis Dâr al-Ma'ârif.

Barker, Robert. 1987. The Sosial Work Dictionary, Maryland: Silver Spring.

Ad-Dâramî. Abdullah bin Abdurrahman Abû Muhammad, t.th. Sunan adDâramî, Beirût : Dâr al-Kitâb al-'Arabî.

Ad-Dâruquthnî al-Baqhdâdî. 'Alî bin 'Umar Abû Husain, 1966M/ 1386H. Sunan adDarâquthnî, Beirut: Dâr Ma'rifah.

Djazuli, 2000. Fiqh Jinayah, Jakarta: PT Raja Grafindo.

Hanafi. Ahmad, 1993. Asas-Asas Hukum Pidana Islam, Jakarta: Bulan Bintang.

Hurairah, Abu. 2005. Kekerasan Terhadap Anak, Bandung: Nuansa.

Ibn Khuzaimah Abû Bakar as-Silmî anNaisabûrî. Muhammad bin Ishâk, 1390 H/ 1970M. Shahîh Ibnu Khuzaimah, Beirût : Maktab al-Islâmî.
Ibnu Rusyd al-Hâfid. Abû al-Walîd Muhammad bin Ahmad bin Muhammad bin Ahmad bin Rusyd al-Qurtubî bin, 1995. Bidayatul Mujtahid, Libanon: Dâr alFikr.

Jalâluddîin as-Suyûtî, t.th. Jâmi' al-Hadîs,

Jalâl ad-Dîn Muhammad bin Ahmad alMahalî dan Jalâl ad-Dîn 'Abdur arRahman bin Abî Bakr as-Syuyûtî. t.th.. Tafsîr al-Jalâlain. Kairo : Dâr al-Hadîs. t.th..

Majelis Umum PBB, Convention On The Rigts Of The Child, Diselenggarakan di New York 1990

Muhammad Nabîl Kâdzim. 2009. Mendidik Tanpa Memukul. Solo: Abyan Solo.

Muslich. Ahmad Wardi, 2005. Hukum Pidana Islam, Jakarta: Sinar Grafika.

Muzakarah Ulama Kerjasama Departemen Agama, Majelis Ulama Indonesia, dan UNICEF Jakarta, Memelihara Kelangsungan Hidup Anak Menurut Ajaran Islam, Jakarta: Panitia Muzakarah Ulama, 1988

An-Naysaburî, Abû Ishâq Ahmad bin Muhammad bin Ibrâhîm as-Tsa'labî. 200M/1422H. al-Kasyfu wa al-Bayân, Beirût: Dâr at-Turâst al-'Arabî.

Tafsîr as-Tsa'labî, t.th.,

UU No. 23 Tahun 2002 tentang Perlindungan Anak.

UU No. 35 Tahun 2014 tentang Perubahan UU No. 23 tahun 2002 tentang Perlindungan Anak. 